\title{
Modelling Experiences And Its Factors In General Mathematics: The Case Of Grade 11 Students
}

\author{
Leomarich F. Casinillo ${ }^{1}$, Emily L. Casinillo² \\ 1,2Department of Mathematics and Physics \\ Visayas State University \\ Visca, Baybay City, Leyte, Philippines \\ e-mails: leomarich_casinillo@yahoo.com; elagumbay12201990@gmail.com
}

\begin{abstract}
Student's experiences in learning plays an essential role in producing quality academic achievement. This study aimed to develop multiple regression models on the students' experiences in learning mathematics in regards to its influencing factors. A simple random sampling of 112 grade 11 students in the first semester of school year 2018-2019 from Visayas State University were used as the respondents of this study. Result of the study reveals that grade 11 students' learning experience in general mathematics is challenging and logical. However, it is found out that it is satisfying and rewarding since it develops their critical thinking and decision making in real life. The number of hours in studying and studying with internet positively influence the students' learning experience in mathematics. It is also revealed that STEM students are more fond learning mathematics compare to non-STEM students. Furthermore, result also shows that a conducive learning environment and religious activities in the campus helps the students to have a peaceful and positive learning experience.
\end{abstract}

Keywords: Learning Experiences; Influencing Factors; General Mathematics; Grade 11 Students; Multiple Regression Model

\section{Introduction}

Mathematics education is a social activity between students and teachers. According to Akinsola and Tella (2007), mathematics is an important subject since it is associated with more career opportunities and also one of the compulsory and mandatory requirement subjects for higher institutions. Seemingly, mathematics learning experience and development of students in school environment is affected by socio-economic factors (Bradley \& Corwyn, 2002; Das \& Sinha, 2017), student's learning factors (Casinillo, 2019), cultural factors (Casinillo et al., 2020a) and socio-demographic profile (Geist \& King, 2008). Nowadays, educational experiences and its relationship with different students' factors is one of the persistent issues in social studies and educational research. According to the study of Code and colleagues (2016), a progressive learning experience in mathematics leads to active engagement and greater interaction between students and a mathematics teacher. Investigating the factors affecting the student's learning experiences and performance can improve the variety of teaching strategies and pedagogical approaches (Casinillo \& Guarte, 2018). This can address the diversity of developmental stages of students and enhanced the formation of sound and transferable of mathematical concepts (Ma, 2003). Furthermore, assessment of learning experience can be used for the improvement of mathematics achievement (Casinillo et al., 2020b).

In Visayas State University (VSU), it offers a senior high school program with different strands and all these students will have to take General Mathematics as one of their required subjects in their curriculum. The different strands are the following: Science, Technology, Engineering, and Mathematics (STEM), Technical-Vocational and Livelihood Tracks (TVL), Accountancy, Business and Management (ABM), Humanities and Social Sciences (HUMSS). Grade 11 students in VSU face a numerous barriers and challenges that affects their overall achievement level in mathematics. Perhaps, the senior high school program in VSU is a new program and some teachers are adjusting to their teaching pedagogy to meet that students' needs. Also, their curriculum program has a lot of subjects that is required every semester and students' time is so difficult to allocate for different activities and school requirements. Hence, these grade 11 students have different learning experiences in mathematics that is 
associated with different factors as well as backgrounds. According to the findings of Şen (2013), negative behavior or attitudes towards learning mathematics are affected by different cognitive factors and prior experiences. Seemingly, this negative learning experience translate to a bad achievement level in mathematics subjects which resulted to failing grades (Casinillo, 2019). To date, there are limited studies in literature that deals with modelling learning experiences in mathematics and its influencing factors. Hence, the study is conducted to determine the different learning experiences and its determinants among grade 11 students in VSU to improve its mathematics education.

The general objective of this study is to capture some factors that significantly influence the learning experiences of grade 11 students in mathematics. The specific objectives are the following: to determine the socio-demographic profile of grade 11 students; to evaluate the different types of learning experiences of grade 11 students; and to develop a multiple regression model that determines the influencing factors of over-all learning experience of grade 11 students. Significance of this study was to present statistically significant factors that influence students' learning experiences that might improve their achievement level in mathematics. In fact, findings of this study will improve the teaching strategy of the mathematics educators and progress the mathematics curriculum of senior high level. Furthermore, this study can also be a guide for school administrators and contributes to the body of literature in terms of improving students' academic performance in the area of science and mathematics.

\section{Methods}

This study employed a descriptive and inferential statistical method that described and determined significant factors affecting the learning experiences in mathematics among senior high students. The research design of this paper is based on the current study of Casinillo and Aure (2018) that deals with regression analysis. For descriptive statistics in this study, the following measures was used: frequencies, proportions or percentages, mean, standard deviation, minimum and maximum. And under the inferential statistics, a multiple regression analysis was undertaken to model and determined statistically significant factors of student's learning experiences.

The response of all grade 11 senior high students who enrolled General Mathematics during the first semester of school year 2018-2019 in Visayas State University was employed. The Slovin's formula was used in determining the sample size by setting the margin of error to $3 \%$ and computed as follows

$$
n=\frac{N}{1+N e^{2}}
$$

where $n$ refers to the sample size, $N$ refers to the population size and $e$ refers to the margin of error (Cochran, 1953). The sample participants were chosen using simple random sampling method. Alternative sample is drawn given that the student are not available, refuse to participate, and does not give accurate answers in the survey. Students who participated but leaves several missing data in the questionnaire were excluded in the number of participants. The distribution of senior high students (grade 11) who participated in this study is shown in Table 1.

Table 1. Distribution of participants and its percentages

\begin{tabular}{cccc}
\hline & $\begin{array}{c}\text { Number of Students } \\
\text { enrolled }\end{array}$ & $\begin{array}{c}\text { Participants of the } \\
\text { study }\end{array}$ & $\begin{array}{c}\text { Percentage } \\
(\%)\end{array}$ \\
\hline Grade 11 & 124 & 112 & 90.32 \\
\hline
\end{tabular}

Before answering the questionnaire, the grade 11 students were oriented on the aim and significance of the study. Furthermore, these students were informed that the information 
gathered from them will be treated with maximum confidentiality and their participation was strictly voluntary.

Prior to the conduct of this study, the permission of the Visayas State UniversitySenior High school (VSU-SHS) principal was requested through a formal letter. The level of learning experiences in mathematics is paramount measured during the actual classroom environment. Thus, by simple random sampling, primary data was gathered using a developed and self-completed questionnaire during the mid-period of the semester to determine the socio-demographic profile, level of learning experiences in general mathematics, and its influencing factors among grade 11 students. The research questionnaire of this study contains a mixture of open-ended and closed-ended which is designed to collect a variety of rich information to students (Sharp, 2012). In the demographic profile of the students, they were asked about the following: age (in years), gender $(1=$ male, $0=$ female), Hometown $(1=$ Urban, $0=$ Rural), weekly allowance (in peso), internet usage in studying mathematics ( $1=y e s, 0=$ no), STEM strand ( $1=y e s, 0=$ no), weekly study hours in mathematics (in hours), and distance from home to school (in kilometers). For other factors in learning experiences in mathematics, a 7-item scale was ask using a 10-point Likert scale, that is, 1-Very unsatisfied and 10-Very satisfied. These factors were the following: Perception to teacher, classroom environment, studying in library, sports activities, religious activities, social relationships and health conditions. Using a Statistical Packages for Social Sciences (SPSS) v.20, it is found out that this instrument was valid and reliable with Cronbach's $\alpha$ equal to 0.81 . For dependent variable of the study, the questions are focusing on students' learning experiences in mathematics such as: Routinely, creative, challenging, enjoyable, logical and rewarding. This is also completed by choosing a scale from 1 to 10: 1 being very unsatisfied and 10 being very satisfied. Again, this Likert scale questions has undergone pre-testing and reliability test and it is found out that the Cronbach's $\alpha$ is equal to 0.90 which implies that it is valid and reliable. In evaluating the learning experiences of grade 11 students in mathematics, the mean perception score was used. Tables 2 shows the different range of values of the mean of perception scores of the students and its corresponding description.

Table 2. Evaluation of Learning Experiences in Mathematics Based on The Mean Perception

\begin{tabular}{ll} 
& Score \\
\hline Range of Mean Perception Score & Description \\
\hline $1.00-2.80$ & Very unsatisfied \\
$2.81-4.60$ & Unsatisfied \\
$4.61-6.40$ & Neutral \\
$6.41-8.20$ & Satisfied \\
$8.21-10.00$ & Very satisfied \\
\hline
\end{tabular}

\section{Data Analysis and Multiple Regression Model}

Descriptive measures was computed to evaluate the variables in the survey. For the multiple regression models, the over-all mean perception score of learning experience of grade 11 students was employed as the dependent variable of the study. This perception score was used to compare levels in an absolute sense, that is, in the regression model it was treated as continuous variable. Then, the Ordinary Least Square (OLS) was considered in this analysis. This OLS estimation procedure involves 3 important valuation such as to estimate the values of the regression parameters, variance of the error term's probability distribution and the variance of the coefficient estimate's probability distribution (Stock \& Watson, 2007; Gelman \& Hill, 2007). The first regression model in this study is given by:

$$
\begin{gathered}
\text { LExpereince }_{i}=\beta_{0}+\beta_{1} \text { Age }_{i}+\beta_{2} \text { Male }_{i}+\beta_{3} \text { Urban }_{i}+\beta_{4} \text { Allowance }_{i}+\beta_{5} \text { Internet }_{i} \\
+\beta_{6} \text { STEM }_{i}+\beta_{7} \text { Num_hours }_{i}+\beta_{8} \text { Distance }_{i}+\varepsilon_{i}
\end{gathered}
$$

where $i$ denotes the $i^{\text {th }}$ grade 11 student in the sample, $\beta_{0}, \beta_{1}, \beta_{2}, \ldots, \beta_{9}$ are parameters to be estimated, $\varepsilon_{i}$ is the random errors, LExpereince $e_{i}$ is the level of perception of students in 
learning general mathematics during the mid-period of the semester (scale of $1-10$ ), $A g e_{i}$ is age of student measured in years, Male $_{i}$ is a dummy variable that captures the male student ( $1=$ male and $0=$ female), $\operatorname{Urban}_{i}$ is a dummy variable that captures a student who lives in urban place ( $1=$ urban and $0=$ rural), Allowance Alefers $_{i}$ to the student's weekly allowance in peso, Internet $t_{i}$ is a dummy variable that captures a student who use internet in studying general mathematics ( $1=y e s$ and $0=n o), S T E M_{i}$ is a dummy variable that captures a STEM student ( $1=$ yes, $0=$ no), Num_hours $s_{i}$ refers to the student's number of hours in studying general mathematics per week, Distance $_{i}$ refers to the student's distance from home to school measured in kilometers. The second multiple regression model is given by:

$$
\begin{aligned}
\text { LExpereince }_{i}=\theta_{0} & +\theta_{1} \text { Per_teacher }_{i}+\theta_{2} \text { Class_envi }_{i}+\theta_{3} \text { Stud_Lib }_{i}+\theta_{4} \text { Sprts_act }_{i} \\
& +\theta_{5} \text { Rel_act }_{i}+\theta_{6} \text { Soc_rltnsh }_{i}+\theta_{7} \text { Health_con }_{i}+u_{i}
\end{aligned}
$$

where $j$ denotes the $j^{\text {th }}$ students in the sample, $\theta_{0}, \theta_{1}, \theta_{2}, \ldots, \theta_{8}$ are parameters to be estimated, $u_{j}$ is the random error in the model, LExpereince $_{i}$ is the level of perception of students in learning general mathematics during the mid-period of the semester (scale of 110), Per_teacher ${ }_{i}$ refers to the perception of students to their mathematics teacher (scale of 1-10), Class_envi $i_{i}$ refers to the level of perception of students in the classroom environment (scale of 1-10), Stud_Lib $b_{i}$ refers to the perception of students in studying in the school library (scale of 1-10), Sprts_act ${ }_{i}$ refers to the perception of students in their sports activities, Rel_act $_{i}$ refers to the perception of students in their religious activities, Soc_rltnshp $p_{i}$ refers to the perception of students to their social relationships, Health_con $i$ refers to the perception of students to their health conditions. In interpreting the OLS model, $\beta_{t}$ is the approximate change in the level of learning experiences in every 1 unit change in the explanatory variable $x_{t}$ while holding other factors constant. According to O'Connell \& Liu (2011), diagnostic tests must be performed to determine whether the necessary assumptions were valid before performing inference to the parameters of interest. Hence, Breusch-Pagan test was employed to capture the heteroscedasticity of the model and Ramsey RESET test was used to determine if the model has omitted variables bias. For the multicollinearity test in the model, Variance Inflation Factor (VIF) was computed which estimates how much the variance of a coefficient is inflated because of linear dependence with other predictors (Allison, 2012). A rule of thumb indicates that the mean VIF value should not be greater or equal to 10 to safely ignore a multicollinearity problem. In determining the normality of residuals, the Shapiro-Wilk test and the Kernel density estimate was performed (Stock \& Watson, 2007). All statistical calculations was employed with the aid of STATA v.14.

\section{Results and Discussion}

\section{Descriptive Analysis of the Survey}

In Table 3, it shows that the age of the grade 11 students ranges from 16 to 18 years old $(\mu=16.76, \sigma=0.60)$, and there are $38 \%$ males and $62 \%$ females. About $43 \%$ of the students live in urban places and $57 \%$ live in rural areas. On the average, the students' weekly allowance is closed to 535.84 $\mathrm{PhP}$ (Min=40, Max=3000). Most of the students with low weekly allowances were the students residing near VSU and students with bigger allowance were students in other places far from the school. This also implies that student's with bigger allowances are with family with higher income. Table 3 reveals that about 13.25 $\mathrm{km}$ (Min=0.10, Max=135) is the student's average distance from home to the campus. About $70 \%$ of the students are studying with internet and $30 \%$ of them are just relying on their notes provided by the teachers. There are $61 \%$ of the students who took up STEM strands and $39 \%$ are of other strands. This means that most of the students are expected to be fond of mathematics. Only 3.06 hours per week was devoted for studying general mathematics. It can be gleaned that grade 11 students were not allotting more time (Min=0, Max=35) in studying the said subject. Some students are just relying on their stock knowledge and do 
not allocate time for review. The students' perception to their general mathematics teacher was high $(\mu=8.78, \sigma=1.64)$. This means that these grade 11 students positively perceived their teacher in terms of expertise and how they present the lessons in mathematics. Classroom environment is also rated good $(\mu=8.78, \sigma=2.38)$, which means that students find VSU as conducive place to study mathematics. However, the VSU library is rated relatively low $(\mu=6.54, \sigma=2.21)$ since students prefer to use internet if they have to search for something in mathematics which they found it more convenient. Religious activities in VSU is rated ( $\mu=6.67, \sigma=2.31$ ) relatively low. This implies that there are students who don't like spending their time for religious activities and spend it for other undertakings. Furthermore, sport activities $(\mu=7.19, \sigma=2.25)$, social relationships ( $\mu=7.63, \sigma=1.55)$, and health condition $(\mu=7.02, \sigma=2.08)$ are rated relatively high. Hence, this goes to infer that these students, on the average, are sports minded, socially oriented, and healthy.

Table 3. Descriptive Measures for Socio-Economic Variables of The Senior High Students

$$
(n=112)
$$

\begin{tabular}{|c|c|c|c|c|}
\hline Socio-economic variables & Mean & $\begin{array}{l}\text { Standard } \\
\text { deviation }\end{array}$ & Minimum & Maximum \\
\hline Age (in years) & 16.7678 & 0.6000 & 16 & 18 \\
\hline Male (dummy) & 0.3750 & 0.4863 & 0 & 1 \\
\hline Urban (dummy) & 0.4286 & 0.4971 & 0 & 1 \\
\hline Weekly Allowance ${ }^{\mathrm{a}}$ & 535.8482 & 390.9413 & 40 & 3000 \\
\hline $\begin{array}{l}\text { Studying with Internet } \\
\text { (dummy) }\end{array}$ & 0.6964 & 0.4618 & 0 & 1 \\
\hline STEM strand (dummy) & 0.6071 & 0.4906 & 0 & 1 \\
\hline Number of hours studying & 3.0571 & 3.7204 & 0 & 35 \\
\hline Distance from home to school $^{\text {b }}$ & 13.2497 & 22.3011 & 0.1 & 135 \\
\hline Perception to teacher ${ }^{c}$ & 8.7827 & 1.6352 & 3 & 10 \\
\hline Classroom environment $^{\mathrm{c}}$ & 7.2589 & 2.3814 & 1 & 10 \\
\hline Studying in library ${ }^{c}$ & 6.5446 & 2.2133 & 1 & 10 \\
\hline Sports activities ${ }^{\mathrm{c}}$ & 7.1964 & 2.2495 & 1 & 10 \\
\hline Religious activities $^{c}$ & 6.6696 & 2.3109 & 1 & 10 \\
\hline Social relationship $^{c}$ & 7.6362 & 1.5458 & 3 & 10 \\
\hline Health condition $^{c}$ & 7.0178 & 2.0838 & 2 & 10 \\
\hline
\end{tabular}

Note: $\quad a$ - Philippine Peso (PhP); b - in kilometres; $c$ - Scale 1 to 10.

\section{Learning Experiences in General Mathematics}

Table 4 shows the six (6) types of learning experiences that students faced on general mathematics and its corresponding descriptions. Firstly, students is neutral on the routine activities of mathematics learning. It implies that students' learning experience in mathematics is unpredictable unlike any other subjects which only requires memorizing. Seemingly, according to the study of Riley et al. (2017), routines are an essential part of mathematics teaching-learning process since it can give structure to time and interactions between teacher and student. On the average, students says that they are neutral on mathematics in terms of being creative in their lesson. Creativity is whereby something new ideas will generate to student's mind and somehow valuable concept is formed. Table 7 shows that even if learning mathematics is quite challenging but students shows interest and satisfaction. And due to the challenging nature of mathematics, students are neutral to their enjoyment in learning process. Also, it can be gleaned that mathematics for them is logical and rewarding (Table 4). 
Indonesian Journal of Educational Research and Review, Vol. 3 No. 2, Tahun 2020

P-ISSN: 2621-4792, E-ISSN: 2621-8984

Table 4. Descriptive measures for different experiences of the senior high students in learning general mathematics $(n=112)$.

\begin{tabular}{|c|c|c|c|}
\hline Learning experiences & Mean & Standard deviation & Description $\left(^{*}\right)$ \\
\hline Routinely $^{\mathrm{c}}$ & 5.9018 & 2.2054 & Neutral \\
\hline Creative $^{c}$ & 5.7679 & 2.1851 & Neutral \\
\hline Challenging ${ }^{c}$ & 7.3661 & 2.0489 & Satisfied \\
\hline Enjoyable $^{\mathrm{c}}$ & 6.1696 & 2.2972 & Neutral \\
\hline Logical $^{c}$ & 7.1875 & 2.1749 & Satisfied \\
\hline Rewarding ${ }^{c}$ & 6.8482 & 2.4539 & Satisfied \\
\hline Over all mean ${ }^{c}$ & 6.5402 & 1.8208 & Satisfied \\
\hline
\end{tabular}

Note: $c$ - Scale 1 to $10 ;{ }^{*}$ - see Table 2.

\section{Multiple Regression Models}

In Table 5, the two multiple regression models explained the statistically significant factors of learning experiences of grade 11 students in general mathematics. In the first OLS model, the Breusch-Pagan test indicated that it is not heteroskedastic $\left(\chi^{2}=0.95, p\right.$ value $=0.33)$ and it has no omitted variables bias $(F=1.25, p$-value $=0.29)$ by Ramsey RESET test. There is no multicollinearity problem in the first model since the mean VIF is equal to 1.10 (Table 5). Furthermore, the residuals are not normal by Shapiro-Wilk test ( $W=0.96, p$ value $=0.0047$ ), however, the Kernel density estimate graph shows that the residuals are almost normal. The first model $(F=2.88)$ is significant since $p$-value $=0.0062<0.01$ which implies that all coefficients taken together is not equal to zero. OLS model 1 shows that studying with internet, being a STEM students and number of hours are significant factors in learning general mathematics. Further, model shows that the students' age, gender, home town, distance from home to school and weekly allowance does not influence their learning experiences in mathematics (Table 5). By Breusch-Pagan test, it was found out that the variances of OLS model 2 is homoscedastic $\left(\chi^{2}=0.57, p\right.$-value $\left.=0.4521\right)$ and by Ramsey RESET test $(F=2.73, p$-value $=0.0476)$, the OLS model 2 has omitted variables bias (Table 5 ). OLS model 2 had no problem of multicollinearity between pair of predictors (mean VIF $=1.64<10$ ) and by Shapiro-Wilk test, it is revealed that the residuals are not normal $(Z=1.903, p$-value $<0.0285)$. However, the Kernel density graph shows that the residuals are close to normality. Table 5 shows that OLS model 2 is significant $\left(\chi^{2}=12.91, p\right.$-value $\left.<0.001\right)$ which implies that the regression determinants explain the variation of the learning experiences of grade 11 students. Classroom environment and religious activities are the only significant predictors of learning experience as shown in Table 5. Furthermore, OLS model 2 reveals that the over-all learning experience of students is not associated with the perception to teacher, studying in the library, sports activities, social relationships and their health conditions.

Table 5. Multiple Regression Models for Senior High Students' Over-All Learning Experiences in General Mathematics As A Dependent Variable And Its Socio-Economic Factors $(n=112)$

\begin{tabular}{|c|c|c|c|}
\hline \multirow{2}{*}{ Socio-Economic Factors } & \multicolumn{2}{|c|}{ Ols Model I } & Ols Model li \\
\hline & COEFFICIENT & STD ERROR & COEFFICIENT STD ERROR \\
\hline Age (in years) & $\begin{array}{l}-0.1287 \\
(0.6510)\end{array}$ & $\begin{array}{c}0.2832 \\
(-0.450)\end{array}$ & \\
\hline Male (dummy) & $\begin{array}{l}-0.3245 \\
(0.3420)\end{array}$ & $\begin{array}{c}0.3399 \\
(-0.950)\end{array}$ & \\
\hline Urban (dummy) & $\begin{array}{c}0.1749 \\
(0.5970)\end{array}$ & $\begin{array}{l}0.3295 \\
(0.530)\end{array}$ & \\
\hline Allowance $^{\mathrm{a}}$ & $\begin{array}{l}0.0002 \\
(0.690)\end{array}$ & $\begin{array}{l}0.0004 \\
(0.400)\end{array}$ & \\
\hline Studying with Internet & $\begin{array}{l}0.9701^{* *} \\
(0.0120)\end{array}$ & $\begin{array}{l}0.3794 \\
(2.560)\end{array}$ & \\
\hline
\end{tabular}


Indonesian Journal of Educational Research and Review, Vol. 3 No. 2, Tahun 2020

P-ISSN: 2621-4792, E-ISSN: 2621-8984

\begin{tabular}{|c|c|c|c|c|}
\hline \multirow{2}{*}{ Socio-Economic Factors } & \multicolumn{2}{|c|}{ Ols Model I } & \multicolumn{2}{|c|}{ Ols Model li } \\
\hline & COEFFICIENT & STD ERROR & COEFFICIENT & STD ERROR \\
\hline (dummy) & & & & \\
\hline STEM strand (dummy) & $\begin{array}{c}0.8444^{* *} \\
(0.023)\end{array}$ & $\begin{array}{l}0.3672 \\
(2.300)\end{array}$ & & \\
\hline Number of hours studying & $\begin{array}{l}0.0732^{*} \\
(0.100)\end{array}$ & $\begin{array}{l}0.0451 \\
(1.620)\end{array}$ & & \\
\hline Distance from home to school ${ }^{b}$ & $\begin{array}{l}0.0011 \\
(0.881)\end{array}$ & $\begin{array}{l}0.0076 \\
(0.150)\end{array}$ & & \\
\hline Perception to teacher ${ }^{c}$ & & & $\begin{array}{c}0.1229 \\
(0.1980)\end{array}$ & $\begin{array}{l}0.0948 \\
(1.300)\end{array}$ \\
\hline Classroom environment $^{c}$ & & & $\begin{array}{c}0.3696^{* * *} \\
(<0.001)\end{array}$ & $\begin{array}{l}0.0810 \\
(4.560)\end{array}$ \\
\hline Studying in library ${ }^{c}$ & & & $\begin{array}{l}0.0894 \\
(0.221)\end{array}$ & $\begin{array}{l}0.0726 \\
(1.230)\end{array}$ \\
\hline Sports activities $^{c}$ & & & $\begin{array}{r}-0.0149 \\
(0.832)\end{array}$ & $\begin{array}{c}0.0704 \\
(-0.210)\end{array}$ \\
\hline Religious activities $^{c}$ & & & $\begin{array}{l}0.1181^{*} \\
(0.096)\end{array}$ & $\begin{array}{l}0.0704 \\
(1.680)\end{array}$ \\
\hline Social relationship $^{c}$ & & & $\begin{array}{l}-0.0516 \\
(0.641)\end{array}$ & $\begin{array}{l}0.1105 \\
(-0.470)\end{array}$ \\
\hline Health condition $^{c}$ & & & $\begin{array}{l}0.0405 \\
(0.604)\end{array}$ & $\begin{array}{l}0.0778 \\
(0.520)\end{array}$ \\
\hline Constant & $\begin{array}{l}7.2240 \\
(0.1280)\end{array}$ & $\begin{array}{l}4.7027 \\
(1.540)\end{array}$ & $\begin{array}{l}1.6052^{*} \\
(0.064)\end{array}$ & $\begin{array}{l}0.8575 \\
(1.870)\end{array}$ \\
\hline F-computed & 2.88 & & 12.91 & \\
\hline p-value & 0.0062 & & $<0.001$ & \\
\hline R-squared & 0.1828 & & 0.4649 & \\
\hline Adjusted R-squared & 0.1194 & & 0.4288 & \\
\hline
\end{tabular}

Note: $a$ - Philippine Peso (PhP); $b$ - in kilometres; $c$ - Scale 1 to 10 . ; $p$-values and $z$ values are enclosed with parenthesis in coefficient and standard error column, respectively; ${ }^{*} p<0.10 ;{ }^{* *} p<0.05 ;{ }^{* * *} p<0.01$

\section{Conclusion and Recomendation}

Result shows that grade 11 students are having fun and motivated to learn mathematical concepts when they are challenge. Also, it is revealed that students' learning experience in mathematics is quiet challenging and logical as well. This is due to the lot of subjects in their curriculum that they are struggling to find time studying mathematics and also due to the tough instructors in college level. This result is somehow consistent to the study of Ruzek and Schenke (2019) that deals classroom perceptions and motivation. In the study of Casinillo et al. (2020b), senior high students in VSU are under with college instructors which makes the problem challenging and students will have to put some effort to solve mathematics problems. It is worth noting that learning mathematics have a variety of opportunities since the application to real life is so diverse. In regards to this, students are satisfied on the analytical and boggling mathematics problems they encountered while learning some skills in mathematics. Perhaps, learning mathematics will build their minds on having the quality or power of creating something original (Beghetto, 2016). Perhaps, it is found out that mathematics for them is rewarding. This is concluded that the benefits of learning mathematics are helpful for them in facing real problems they encountered daily. On the average, the over-all mean shows that grade 11 students are satisfied to their learning experiences in general mathematics. This infers that the learning from mathematics provides satisfaction and fulfillment to the students which is helpful for good academic performance which is consistent to the findings of Ruzek and Schenke (2019).

Results in OLS model 1 is parallel to the findings of Casinillo and Aure (2018) that academic performance in mathematics is independent to demographic profile and allowance of students. Also, it is revealed in OLS model 1 that studying with internet can significantly influence the student's learning experiences. Perhaps, internet is a huge source of information which helps students to find supplemental materials in mathematics aside from 
their lessons in class. Exposing to the modernity makes the students competitive in the society. In the study of Prestridge (2012), and Salam and colleagues (2018), it is stated that modern technology can definitely support the development of particular concepts in class discussions, applications and problem-solving skills of students. Being a STEM student can positively influence the learning experience in mathematics. STEM strand has several mathematics compare to the other senior high students that's why they are fonder in learning the subject. According to Kitchen and colleagues (2018), STEM students are students who find learning mathematics as fascinating and a challenging experience rather than a burden. And in the study of Casinillo and Aure (2018), most of the STEM students has positive perception to mathematics subjects which is a reason to perform well in class. Furthermore, OLS model 1 reveals that the number of hours in studying mathematics can improve the learning experience. Similar to the findings of Kunal (2008), it is observed that students who are successful in their desired career have longer study time.

It is shown in the OLS model 2 that a conducive classroom environment can positively influence the students' learning experience in mathematics (Table 5). This goes to infer that a positive institutional climate can eliminate stress and can positively affects the degree of well-being and achievement level of students (Singh, 2014). Also, a student who involves in religious activities has a good learning experiences in mathematics. According to Riis (2011), an individual tends to feel comfortable and have more confidence if they have belief on the aid of divine providence. In the study of Amaliyah et al. (2017), it is also revealed that religious identity has impacts on education aspects. It is concluded that it gives peace of mind that helps them to study in advantageous way and in harmony as well. However, a good perception to mathematics teacher does not implies a good learning experience. Consistent to the study of Casinillo and Aure (2018) that students' perception to teacher does not influence their academic performance. Table 5 reveals that studying in the library does not significantly influence the over-all learning experiences. This is due to the out dated references available in the library, hence, students prefer to search on the internet for further information.

The school must maintain a conducive classroom environment that can positively influence the students' learning experience which translate to better grades in mathematics. Teacher are endorsed to encourage students to join religious activities which positively impact their learning behavior. It is highly recommended that mathematics teachers should provide appropriate modules, handouts or instructional materials that is suitable for $21^{\text {st }}$ century students. This is to support and improve the students learning experience to progress academic achievement in science and mathematics. A similar research study should be conducted in senior high level with bigger sample size to gather richer information and explain better the learning experience in mathematics. This is to improve the existing policy in school administrators and mathematics education curriculum. Furthermore, findings of the study will assess teaching strategies and well-being of students.

\section{References}

Akinsola, M. A. \&Tella, A. (2007). Correlates of academic procrastination and mathematics achievement of university undergraduate students. Eurasia Journal of Mathematics, Science and Technology Education, 3(4), 363-370.

Allison, P. (2012). When Can You Safely Ignore Multicollinearity? Retrieved from http://statisticalhorizons.com/multicollinearity

Amaliyah, S., Anwar, K. \& Nuqul, F. L. (2017). The effect of religious identity toward academic performance: an experimental study. 6th Annual International Conference on Cognitive and Behavioral Psychology (CBP 2017). Retrieved from https://www.researchgate.net/publication/315099787.

Beghetto, R. A. (2016). Creative learning: A fresh look. Journal of Cognitive Education and Psychology, 15(1), 6-23.

Bradley, R. H., \& Corwyn, R. F. (2002). Socioeconomic status and child development. Annual Review of Psychology, 53(1), 371-399. 
Casinillo, L. F. (2019). Factors affecting the failure rate in mathematics: the case of Visayas State University (VSU). Review of Socio-Economic Research and Development Studies, 3(1), 1-18.

Casinillo, L. F. \& Aure, M. R. K. L. (2018). Econometric evidence on academic performance in basic calculus of science, technology, engineering and mathematics (STEM) senior high students. Journal of Educational and Human Resource Development, 6, 238249.

Casinillo, L. F., Camulte, M. C. G., Raagas, D. L. and Riña, T. S. (2020a). Cultural factors in learning mathematics: the case on achievement level among Badjao students. International Journal of Indonesian Education and Teaching, 4(1), 71-81.

Casinillo, L. F. \& Guarte, J. M. (2018). Evaluating the effectiveness of teaching strategies: The case of a national vocational school in Hilongos, Leyte. Review of SocioEconomic Research and Development Studies, 2(1), 64-79.

Casinillo, L. F., Palen, M. A. E., Casinillo, E. L., \& Batidor, P. G. (2020b). Assessing Senior High Student's Learning Experiences in Mathematics. Indonesian Journal of Educational Studies, 23(1), 44-60.

Cochran, W. G. (1953). Sampling Techniques. New York: John Wiley and Sons, Inc.

Code, W., Merchant, S., Maciejewski, W., Thomas, M., \& Lo, J. (2016). The Mathematics Attitudes and Perceptions Survey: an instrument to assess expert-like views and dispositions among undergraduate mathematics students. International Journal of Mathematical Education in Science and Technology, 47(6), 917-937. Retrieved from http://dx.doi.org/10.1080/0020739X.2015.1133854

Das, G. C. \& Sinha, S. (2017). Effect of Socioeconomic status on performance in mathematics among students of secondary schools of Guwahati city. IOSR Journal of Mathematics, 13(1), 26-33.

Geist, E. A., \& King, M. (2008). Different, not better: Gender differences in mathematics learning and achievement. Journal of Instructional Psychology, 35(1;1), 43-52.

Gelman A. \& Hill J. (2007). Data Analysis using Regression and multilevel/Hierarchical models. Cambridge University Press, New York.

Kitchen, J. A., Sonnert, G., \& Sadler, P. M. (2018). The impact of college-and university-run high school summer programs on students' end of high school STEM career aspirations. Science Education, 102(3), 529-547.

Kunal, D. S. (2008). Cultivating competence, self-efficacy and intrinsic interest through proximal self-motivation. Journal of Personality and Social Psychology, 4(3), 586-598.

$\mathrm{Ma}, \mathrm{X}$. (2003). Effects of early acceleration of students in mathematics on attitudes toward mathematics and mathematics anxiety. Teachers College Record, 105(3), 438-464.

O'Connell, A. A., \& Liu, X. (2011). Model diagnostic for proportional and partial proportional odds models. Journal of Modern Applied Statistical Methods, 10(1), 139-175. doi:10.22237/jmasm/1304223240

Prestridge, S. (2012). The beliefs behind the teacher that influences their ICT practices. Computers \& Education, 58(1), 449 458. Retrieved from https://doi.org/10.1016/j.compedu.2011.08.028

Riis, Ole. (2011). Rejection of Religious Pluralism: The Danish Case. Nordic Journal of Religion and Society, 24(1), 19-36.

Riley, N., Lubans, D. R., Holmes, K., Hansen, V., Gore, J., \& Morgan, P. J. (2017). Movement-based mathematics: enjoyment and engagement without compromising learning through the EASY minds program. Eurasia Journal of Mathematics, Science and Technology Education, 1653-1673.

Ruzek, E. A., \& Schenke, K. (2019). The tenuous link between classroom perceptions and motivation: A within-person longitudinal study. Journal of Educational Psychology, 111(5), 903-917.

Salam, S., Zeng, J. Q., Pathan, Z. H., Latif, Z., \& Shaheen, A. (2018). Impediments to the Integration of ICT in Public Schools of Contemporary Societies: A Review of 
Literature. Journal of Information Processing Systems, 14(1), 252-269. Retrieved from https://doi.org/10.3745/JIPS.04.0062

Sharp, J. (2012). Success with your education research project (2nd edition). Sage. London, England.

Şen,H. S. (2013). The attitudes of university students towards learning. Procedia-Social and Behavioral Sciences, 83, 947 - 953.

Singh, A. (2014). Conducive Classroom Environment in Schools. International Journal of Science and Research, 3(1), 387-392.

Stock, J. H. \& Watson, M. W. (2007). Introduction to Econometrics. $2^{\text {nd }}$ edition. Boston: Pearson Addison Wesley. 